\title{
Correction to: Professional Competence of Vocational Teachers: a Conceptual Review
}

\section{Sofia Antera ${ }^{1}$}

Published online: 1 December 2021

(c) Springer Nature B.V. 2021

\section{Correction to: Vocations and Learning (2021) 14:459-479 https://doi.org/10.1007/s12186-021-09271-7}

The original version of this article unfortunately contained an error.

Many of the in-text references have not been linked to the reference list. Below are the missing reference in the list.

1. Adams, E. (2010). A framework for the preparation of accomplished career and technical education teachers. Journal of Career and Technical Education, 25(1), 21-34.

2. Adomaitienè, J., \& Zubrickienè, I. (2010). Career competences and importance of their development in planning of career perspective. Bridges / Tiltai, 53(4), 87-99.

3. Alazzam, A.-O., Bakar, A.-R., Hamzah, R., \& Asimiran, S. (2012). Effects of demographic characteristics, educational background, and supporting factors on ICT readiness of technical and vocational teachers in Malaysia. International Education Studies, 5(6), 229-243. https://doi.org/10.5539/ies.v5n6p229

4. Amiartuti K., Endang S. (2015). Teacher performance of the state vocational high school teachers in Surabaya. International Journal of Evaluation and Research in Education (IJERE), 4 (2), 76-83. https://doi.org/10.11591/ijere. $\mathrm{v} 4 \mathrm{i} 2.4495$

5. Andersson, P., Hellgren, M., \& Köpsén, S. (2018). Factors influencing the value of CPD activities among VET teachers. International Journal for Research in Vocational Education and Training, 5(2), 140-164. https://doi.org/10.13152/ IJRVET.5.2.4

6. Andersson, P., \& Köpsén, S. (2017). Maintaining competence in the initial occupation: Activities among vocational teachers. Vocations and Learning, 11(2), 317-344. https://doi.org/10.1007/s12186-017-9192-9

The original article can be found online at https://doi.org/10.1007/s12186-021-09271-7.

Sofia Antera

sofia.antera@edu.su.se

1 Department of Education, Stockholm University, Stockholm, Sweden 
7. Andryukhina, L. M., Dneprov, S. A., Sumina, T. G., Zimina, E. Y., Utkina, S. N., \& Mantulenko, V. V. (2016a). The model of monitoring of vocational pedagogical competences of professors in secondary vocational education. International Journal of Environmental and Science Education, 11(14), 7016-7034.

8. Andryukhina, L. M., Dneprov, S. A., Sumina, T. G., Zimina, E. Y., Utkina, S. N., \& Mantulenko, V. V. (2016b). Vocational pedagogical competencies of a professor in the secondary vocational education system: Approbation of monitoring model. International Journal of Environmental and Science Education, 11(14), 7045-7065.

9. Attaochu, E. U. (2013). Quality assurance of teachers in the implementation of the curriculum of technical and vocational education in colleges of education (technical) in north central Nigeria. International Journal of Adult Vocational Education and Technology, 4(2), 34-43. IGI Global.

10. Barrick, R. K., Roberts, T. G., Samy, M. M., Thoron, A. C., \& Easterly, R. G., III. (2011). A needs assessment to determine knowledge and ability of Egyptian agricultural technical school teachers related to supervised agricultural experience. Journal of Agricultural Education, 52(2), 1-11. https://doi.org/10.5032/ jae.2011.02001

11. Cannon, J., Kitchel, A. Duncan, D. (2010). Identified perceived professional development needs of Idaho secondary CTE teachers: Programme management needs of skilled and technical science teachers. Journal of STEM Teacher Education, 47(1), 42-69.

12. Danielová, L., Janderková, D., \& Horáčková, M. (2011). Analysis of educational needs of student teachers at the Institute of Lifelong Learning at Mendel University in Brno. Acta Universitatis Agriculturae et Silviculturae Mendelianae Brunensis, 59(7), 97-104. https://doi.org/10.11118/actaun201159070097

13. Dorozhkin, E. M., Tarasyuk, O. V., Lyzhin, A. I., Krotova, O. P., \& Sherstneva, N. L. (2016). Structural and functional model of training future masters of vocational training for the organization of teaching and the production process in terms of networking. International Journal of Environmental and Science Education, 11(15), 8323-8334.

14. Duch, H., \& Andreasen, K. E. (2017). VET Again: Now as a VET teacher. International Journal for Research in Vocational Education and Training, 4(3), 289-305. https://doi.org/10.13152/IJRVET.4.3.6

15. Dudung, A. (2018). Competency test result of vocational school teacher's majoring light vehicles subject in East Jakarta. AIP Conference Proceedings, 1941(1), 1-12. https://doi.org/10.1063/1.5028064

16. Esmond, B., \& Wood, H. (2017). More morphostasis than morphogenesis? The "dual professionalism" of English further education workshop tutors. Journal of Vocational Education and Training, 69(2), 229-245. https://doi.org/10.1080 /13636820.2017.1309568

17. Falco, V. P., Fedorov, V. A., Dorozhkin, E. M., Merkushova, N. I., \& Bakanach, O. V. (2016). Forming artistic-design competency of vocational design teacher. International Journal of Environmental and Science Education, 11(16), 9266-9284. 
18. Fedulova, K., Fedulova, M., Kirillova, Y., Vagina, A., \& Kuznetsov, T. (2017). Special competence in the structure of vocational pedagogical integrity in the sphere of vocational education. Eurasian Journal of Analytical Chemistry, 12(7b), 1265-1273. https://doi.org/10.12973/ejac.2017.00252a

19. Gridneva, S., Vasyakin, B., Ovsyanik, O., Pozharskay, E., \& Berezhnaja, M. (2017). Modern health improving psychotechnologies of a higher school teacher's personality. Eurasian Journal of Analytical Chemistry, 12(5b), 823-834. https://doi.org/10.12973/ejac.2017.00214a

20. Guzanov, B. N., Tarasyuk, O. V., Bashkova, S. A., Ustakova, D. A., \& Sotskova, S. I. (2016). The structural and functional model of development of professionoriented and specialized competences of students at vocational and pedagogical higher educational establishments. International Journal of Environmental and Science Education, 11(16), 9222-9238.

21. Köpsén, S., \& Andersson, P. (2017). Reformation of VET and demands on teachers' subject knowledge-Swedish vocational teachers' recurrent participation in a national CPD initiative. Journal of Education and Work, 30(1), 69-83. https://doi.org/10.1080/13639080.2015.1119259

22. Köpsén, S. (2014). How Vocational teachers describe their vocational teacher identity. Journal of Vocational Education and Training, 66(2), 194-211. https:// doi.org/10.1080/13636820.2014.894554

23. Malik, M., Soenarto, S., \& Sudarsono, F. (2018). The competency-based training model for vocational high school teachers from electrical expertise programs. Jurnal Pendidikan Vokasi, 8(3), 313-323. https://doi.org/10.21831/jpv. v8i3.19877

24. Manley, R. A., \& Zinser, R. (2012). A Delphi study to update CTE teacher competencies. Education \& Training, 54(6), 488-503. https://doi. org/10.1108/00400911211254271

25. Navarro, S. B., Zervas, P., Gesa, R. F., \& Sampson, D. G. (2016). Developing teachers' competences for designing inclusive learning experiences. Educational Technology \& Society, 19(1), 17-27.

26. Neupokoeva, E., Chapaev, N., Chubarkova, E., Tolstova, N., Fedulova, K., \& Tokar, A. (2017). Peculiarities of preparation of a vocational teacher for use of application software taking into account the requirements of the Federal State Education Standard. Eurasian Journal of Analytical Chemistry, 12(7b), 1383-1398. https://doi.org/10.12973/ejac.2017.00265a

27. Nissilä, S-P., Karjalainen, A., Koukkari, M., \& Kepanen, P. (2015). Towards competence-based practices in vocational education-What will the process require from teacher education and teacher identities? Center for Educational Policy Studies Journal, 5(2), 13-34.

28. O'Connor, P. J. (2012). The Professional development needs of academic teachers adding career-technical education licenses. Journal of Career and Technical Education, 27(1), 34-47. https://doi.org/10.21061/jcte.v27i1.538

29. Piskunova, E., Sokolova I., \& Kalimullin, A. (2016). The problem of correspondence of educational and professional standards (results of empirical research). International Journal of Environmental and Science Education, 11(6), 1003-1010. https://doi.org/10.12973/ijese.2016.509a 
30. Poortman, C. L., Illeris, K., \& Nieuwenhuis, L. (2011). Apprenticeship: From learning theory to practice. Journal of Vocational Education and Training, 63(3), 267-287. https://doi.org/10.1080/13636820.2011.560392

31. Ramadan, A., Chen, X., \& Hudson, L. L. (2018). Teachers' skills and ICT integration in Technical and Vocational Education and Training TVET: A Case of Khartoum State-Sudan. World Journal of Education, 8(3), 31-43. https://doi. org/10.5430/wje.v8n3p31

32. Redmond, P. (2017). VET practitioner's perceptions of VET higher-education qualifications. International Journal of Training Research, 15(1), 55-70. https:// doi.org/10.1080/14480220.2017.1313170

33. Saimbetova, Z. Sarbassova, K., Mukhtarova, S., M., Bekmagambetov, A., Kaltayeva, G. (2017). Competence approach to developing ethical-cultural personality of future teachers of vocational training, Man in India, 97(6), 327-344. Serials Publications.

34. Sartori, R., Tacconi, G., \& Caputo, B. (2015). Competence-based analysis of needs in VET teachers and trainers: An Italian experience. European Journal of Training and Development, 39(1), 22-42. https://doi.org/10.1108/EJTD-092013-0089

35. Schmidt, T. (2017). Context and capabilities: Tensions between managers' and teachers' views of advanced skills in VET. International Journal of Training Research, 15(1), 41-54. https://doi.org/10.1080/14480220.2017.1331862

36. Smith, E., \& Yasukawa, K. (2017). What makes a good VET teacher? Views of Australian VET teachers and students. International Journal of Training Research, 15(1), 23-40. https://doi.org/10.1080/14480220.2017.1355301

37. Southren, M. (2015). Working with a competency-based training package: A contextual investigation from the perspective of a group of TAFE teachers. International Journal of Training Research, 13(3), 194-213. https://doi.org/10 $.1080 / 14480220.2015 .1077722$

38. Stephens, G. (2015). Uncertified and teaching: Industry professionals in career and technical education classrooms. International Journal for Research in Vocational Education and Training, 2(2), 119-135. https://doi.org/10.13152/ IJRVET.2.2.4

39. Sudirman, S. Pd. MM. (2017). Efforts to improve teacher competence in developing a lesson plan through sustainable guidance in SMKN 1 Mamuju. Journal of Education and Practice, 8(5), 114-119.

40. Sutarto, H.P., \&, Jaedun, M.P.D. (2018). Authentic assessment competence of building construction teachers in Indonesian vocational schools. Journal of Technical Education and Training, 10(1), 91-108.

41. Tambunan, H. (2014). Factors affecting teachers' competence in the field of information technology. International Education Studies, 7(12), 70-75. https:// doi.org/10.5539/ies.v7n12p70

42. Tarekegne, C., Wesselink, R., Biemans, H. J. A., \& Mulder, M. (2017). Developing and validating a competence profile for development agents: An Ethiopian case study. Journal of Agricultural Education and Extension, 23(5), 427-441. https://doi.org/10.1080/1389224X.2017.1368400 
43. van Dam, K., Schipper, M., \& Runhaar, P. (2010). Developing a competencybased framework for teachers' entrepreneurial behaviour. Teaching \& Teacher Education, 26(4), 965-971. https://doi.org/10.1016/j.tate.2009.10.038

44. van Uden, J. M., Ritzen, H., \& Pieters, J. M. (2013). I think I can engage my students. Teachers' Perceptions of student engagement and their beliefs about being a teacher. Teaching and Teacher Education: An International Journal of Research and Studies, 32, 43-54. https://doi.org/10.1016/j.tate.2013.01.004

45. Wu, M., Huang, C., Kao, Y., Lue, Y., \& Chen, L. (2018). Developing a Professional Performance Evaluation System for Pre-Service Automobile Repair Vocational High School Teachers in Taiwan. Sustainability, 10(10), 3537. https://doi.org/10.3390/su10103537

The original article has been corrected.

Publisher's Note Springer Nature remains neutral with regard to jurisdictional claims in published maps and institutional affiliations. 